\title{
The empirical analysis of financial reports of companies in Croatia: Benford distribution curve as a benchmark for first digits
}

\author{
Ivana Cunjak Mataković \\ Centar-revizija d.o.o., Croatia \\ ivana.cunjak@gmail.com
}

\begin{abstract}
The financial numbers game is unfortunately alive and doing well. One of the forensic accounting techniques is based on Benford's Law and is used for the detection of unusual transactions, anomalies or trends. The aim of this paper is to test whether the financial statements of Croatian companies deviate from Benford's Law distribution. The financial statements of 24 companies that are in the pre-bankruptcy settlement process and 24 companies that are not in the pre-bankruptcy settlement process were analysed using the Benford's Law test of the first digit distribution for the period from 2015 to 2018. The data used to calculate the first digits of distribution were taken from the Zagreb Stock Exchange. The chi-square test has shown that the observed companies that are not in the process of pre-bankruptcy settlement do not have the first digit distribution which follows the Benford's Law distribution. The KolmogorovSmirnov $Z$ test has shown that the distribution of the first digits from the financial statements of companies listed on the Zagreb Stock Exchange fits to Benford's Law distribution.
\end{abstract}

Keywords: Benford's Law, Chi-square goodness-of-fit test, first digits, forensic accounting, Kolmogorov-Smirnov $Z$ test.

JEL classification: C1, G3, M4.

DOI: 10.2478/crebss-2019-0014

Received: October 30, 2019

Accepted: November 29, 2019

\section{Introduction}

The beginning of the $21^{\text {st }}$ century was marked by corporative scandals. The best known have been Enron (USA, 2001), Parmalat Spa (Italy, 2003), Word Com (USA, 2002), Rent-Way (USA, 2000) or Satyam Computers Limited (India, 2009). These scandals raised awareness of fraud in the company's' reports and bring a serious concern of stockholders and investors about the reliability of financial statements. For instance, in 30 financial scandals caused by fraud in the period from 1997 to 2004 the lost market capitalization was more than $\$ 900$ billion, which represents $77 \%$ of their market value (Hogan et al., 2008).

The significant change is made by the Sarbanes-Oxley Act and his section 404, which requires that the company management should assess internal controls over 
financial reporting (Krishnan, Visvanathan, 2007). The adoption of this Act indicates that fraud represents a high-risk in financial reporting. In the 2018 Report to the Nations, the publication issued by the Association of Certificated Fraud Examiners, is a statement that indicates that the tips are the most commonly detected method of fraud. More than half of the tips were provided by employees of the victim organization. One-third of the tips came from persons outside of the organization: customers, vendors or competitors. The swindles discovered by auditors account $4 \%$ (ACFE, 2018). Ten years earlier, the frauds discovered by auditors accounted $9.1 \%$ (ACFE, 2008).

In recent years, forensic accounting is developed as a special filed of auditing. Forensic accounting includes the audit of accounting records in search of evidence of fraud (Singleton, Singleton, 2010). Fraud symptoms can be grouped in various ways such as accounting anomalies, internal control weakness or analytical anomalies (Albrecht, 2009). Special emphasis is put on analytical knowledge and skills to recognize unusual trends or anomalies. One of the statistical methods for the detection of deviations is Benford's Law. Benford's Law is the test of probability for the occurrence of the digits in the first, second, third and fourth positions. Benford's Law is based on logarithmic distribution and it is applied to compare observed values with expected values. Analysis based on Benford's Law will indicate if some of the observed records are anomalous (Nigrini, 2011).

The aim of this paper is to determine whether the financial statements of Croatian companies comply with Benford's Law distribution. In this study, Benford's Law will be applied on financial statements of companies listed on the Zagreb Stock Exchange. The analysed companies will be divided into two categories: 1) the companies that are not in the process of pre-bankruptcy settlement and 2) the companies that are in the process of pre-bankruptcy settlement. The companies that are in the process of the pre-bankruptcy settlement are regulated by the Act on Financial Operations and Pre-Bankruptcy Settlement (further in the text: Act) (Official Gazette, 2012). The Act is aligned with Directive 2011/07/EU on combating late payment in commercial transactions (Hasić, 2014). The pre-bankruptcy settlement procedure is conducted in order to achieve the liquidity and solvency of debtors. The Act defines the obligation to initiate pre-bankruptcy settlement proceedings for debtors (companies) who are illiquid or insolvent and have acquired the conditions to initiate the procedure.

Based on the interest of analysis and the aim of this paper, the main Goodness-ofFit hypotheses can be set as follows:

- Ho: Deviations from Benford's Law distribution do not exist for companies that are not in a process of pre-bankruptcy settlement and for companies that are in a process of pre-bankruptcy settlement; and

- $H_{1}$ : Deviations from Benford's Law distribution exist for companies that are not in a process of pre-bankruptcy settlement and for companies that are in a process of pre-bankruptcy settlement.

The hypothesis of the paper will be tested using the Chi-square goodness-of-fit test and Kolmogorov-Smirnov Z test applied on data from 2015 to 2018. The statistical methods based on the probability of distribution like Benford's Law could be interesting and useful for auditors, accountants, statisticians and controllers.

Paper is structured and organized in five chapters. After the introduction in the second chapter is presented the literature review. Data and methodology are explained in the third chapter. The fourth chapter displays empirical analysis, results and discussion. The key findings are presented in the concluding part of the paper. 


\section{Literature review}

Benford's Law shows expected frequency distribution of the first and other digits in various datasets and therefore could be used to verify the reliability of accounting data. Mark Nigrini presented Benford's Law as an analytical procedure for the detection of financial frauds in the article titled "He's got their number: Scholar use math to foil financial fraud", published in the Wall Street Journal in 1995 (Nigrini, 2011). However, Benford's Law is not limited only to expected patterns of first digits. Nigrini and Miller (2009) developed the mathematical proofs based on Benford's Law to test the frequency of second digits (the second-order test). The second-order test is based on the digit's patterns and it "calculates the digit frequencies of the differences between the ordered (ranked) values in a data sets" (Nigrini, Miller, 2009, 305). The test is designated to detect unusual issues like errors, fraud, outliers or processing inefficiencies (Nigrini, 2011).

Benford's Law can be applied also outside accounting and audit. For instance, Rauch et al. (2011) used Benford's Law to test the reliability of macroeconomic data regarding deficit criteria. This analysis has found that, among all EU states, the data reported by Greece to Eurostat has the largest deviation from expected Benford's Law distribution. Shi, Ausloss and Zhu (2018) analysed reported financial data from ten industrial sectors of the six developing countries (Brazil, China, India, Indonesia, Mexico and Turkey) in the period from 2000 to 2014. Their interest was to determine whether these data comply with Benford's Law. The results indicated that all examined industries differ from the expected Benford's Law first significant digit distribution.

Corazza, Ellero and Zorzi (2010) have analysed whether the first digit of the price/returns of the assets of companies from the S\&P 500's stock follows Benford's Law distribution. They have found that the first digit distribution related to the returns better fits to Benford's Law than the probability distribution related to prices. Shrestha (2016) have analysed financial statements of 20 tech companies of the Fortune 500 such as Amazon, Google, IBM, Apple, eBay, Microsoft, Oracle and Xerox. The results of Benford's Law test have shown that observed data almost followed Benford's Law. Asslani and Naco (2014) applied the principles of Benford's Law for auditing in hospitals. After implementing Benford's Law, methodology authors were able to identify the missing digits in the first and second position. They concluded that additional analysis should be conducted to determine the presence of fraud.

The research conducted in Slovenia by Omerzu and Kolar (2018) tested digits distribution in the financial statements of companies from the Ljubljana Stock Exchange. The analysis included 44 companies listed on the Ljubljana Stock Exchange and have auditor's opinion on financial statements. The observed period was for three years (2011-2013). The analysed data passed the test of the first and the second digit according to Benford's Law.

Krakar and Žgela (2009) applied Benford's Law to test stock prices and the stock turnover of companies listed on the Zagreb Stock Exchange. The authors observed these parameters in the period from January 1998 to February 2008. They have found that closing daily stock price in observed ten-year period do not conform to Benford's Law. However, total daily stock turnovers completely fit to Benford's Law. Slijepčević and Blašković (2014) applied Benford's Law to analyse the annual financial reports of eight publicly owned companies from Croatia for the period of two years and they have found that seven annual reports deviate from Benford's Law. Papić, Vudrić and Jerin (2017) analysed the usage of Benford's Law in forensic accounting. They have analysed 12 randomly chosen companies listed on the Zagreb Stock Exchange in the period from 2011 to 2016. The conducted analysis has shown significant deviations from Benford's Law for all observed companies. The possibilities of Benford's Law 
application in the field of marketing was tested by Jošić and Žmuk (2018). The authors were focused on psychological pricing detection. The research results have shown deviations from Benford's Law and authors concluded that prices are influenced by human thoughts. Dumičić and Cunjak Mataković (2019) tested whether the financial statements from Croatian companies of the food processing industry and the tourism sector fits to Benford's Law distribution of the first digit. They have found that financial statements of companies from the food processing industry deviate from Benford's Law distribution of the first digit.

Blondeau Da Silva emphasised that the proportion of $d$ as a leading digit, $d \in \llbracket 1,9 \rrbracket$, occurring in data is likely to follow the law based on a specific upper bound, rather than Benford's Law (Blondeau Da Silva, 2019). However, it is also important to emphasize that some authors like Diekmann and Jann (2010) have a sceptical opinion about the application of Benford's Law. Diekmann and Jann tried to determine whether Benford's Law distribution is an appropriate method for discovering manipulated and non-manipulated estimates. They have found that further research efforts should be focused more on the quality of the conducted tests and that obtained results should be cautiously interpreted.

\section{Data and methodology}

The occurrence of the first digit's frequencies in randomly selected data is not uniform, and Simon Newcomb, Canadian-American astronomer/mathematician was the first who noted this. When observing logarithmic tables Newcomb saw that, the first pages faster wear out than the last one. In 1881, he published the article "Note on the Frequency of Use of the Different Digits in Natural Numbers" (Phillips, 2009), where he stated: "The law of probability of the occurrence of numbers is such that all mantises of their logarithms are equally likely" (Hill, 1995, 354). He formulated a law stating that every number has led significant digit 1 with probability $\log _{10} \cong 0.301$ leading significant digit 2 with probability $\log _{10}(3 / 2) \cong 0.176$ and so on to probability 0.046 for leading digit 9 (Hill, 1995).

About 57 years later, the physicist Frank Benford rediscovered this law. Benford analysed the first digits of 20,000 entries from 20 various dataset, such as areas of 335 rivers, 1389 chemical compounds, street numbers and American League statistics. However, the results of his analyses have shown that in datasets the observed numbers had the first digit 1 on average of $30.6 \%$, and $18.5 \%$ of the analysed number had a first digit 2. Frank Benford then saw the patterns of his results. He noted that the proportion of the first digit 1 was almost equal to the common logarithm of 2 (or 2/1). This logarithm pattern continued through to the digit 9. Benford then formulated the expected frequencies of the digits in a list of numbers and these frequencies have become known as Benford's Law (Nigrini, 2011), as follows:

$$
P\left(D_{1}=d_{1}\right)=\log _{10}\left(1+\frac{1}{d_{1}}\right) d_{1} \in\{1,2, \ldots 9\},
$$

where $D_{1}$ represents the first digit, $\mathrm{P}$ indicates the probability of occurrence the number in data sets and log refers to the log of the base 10.

Table 1 Expected frequencies of the digits according to Benford's Law

\begin{tabular}{|c|c|c|c|c|c|c|c|c|c|}
\hline First digit & 1 & 2 & 3 & 4 & 5 & 6 & 7 & 8 & 9 \\
\hline Probability & 0.301 & 0.176 & 0.125 & 0.097 & 0.079 & 0.067 & 0.058 & 0.051 & 0.046 \\
\hline
\end{tabular}

Source: Authors' calculation.

Theodore P. Hill, American mathematician, in 1995 gave the theoretical explanation of reasons why Benford's Law is found in many empirical contexts. He 
stated that "if distributions are selected at random (in any "unbiased" way) and random samples are taken from each of these distributions, the significant digits of the combined sample will converge to the logarithmic (Benford) distribution" (Hill, 1995, p. 354). According to Central Limit Theorem, distributions tend to be symmetric, so datasets will tend to follow Benford's Law (Amiram, Bozanic, Roun, 2015).

The general rule is, therefore, that data, when is ranked from smallest to largest will form a geometric sequence. The records should represent the sizes and fact or events. Financial examples include the market values of companies, the revenues of companies or the daily sales volumes. The data should not be built on minimum or maximum values. Records such as identification numbers, telephone numbers or bank account numbers should not be used. Datasets size should have at least 1,000 records (Nigrini, 2011). The datasets will likely follow Benford's distribution if are next condition are met: the mean of an observed set of numbers is larger than the median and the skewness is positive (Durtschi, Hillison, Pacini, 2004).

The Z-statistic test, chi-square test, Kolmogorov-Smirnov $\mathrm{Z}$ test and the mean absolute deviation test can be used to test whether an actual set of the result differs significantly from the expectation of Benford's Law (Nigrini, 2011). The chi-square test and Kolmogorov-Smirnov test will be applied to determine whether the first digits of the observed records follow the expected Benford's Law distribution. The chi-square test $\left(\chi^{2}\right)$ is defined as follows:

$$
\chi^{2}=\sum_{i=1}^{k} \frac{\left(f_{i}-e_{i}\right)^{2}}{e_{i}}
$$

where $f_{i}$ is the real number of the first digit in the sample and $e_{i}$ is the expected number of the first digit in the sample. The null hypothesis is rejected at $5 \%$ significance if the calculated $\chi^{2}$ exceeds the critical value of 15.51 with 8 degrees of freedom. Kolmogorov-Smirnov $Z$ test is a nonparametric statistical test that calculates a distance between of the set of numbers and the cumulative distribution function of the chosen distribution. The Kolmogorov-Smirnov test is defined as follows:

$$
\mathrm{K}-\mathrm{S}=\frac{1.36}{\sqrt{N}}
$$

where 1.36 is constant for a significance level of 0.05 and $\mathrm{N}$ is the number of records (Nigrini, 2011 ).

In this paper will be conducted analysis to determine whether the financial reports of observed companies deviate from Benford's Law distribution. The analysis consists of the following three steps: 1) collecting datasets; 2) descriptive statistics and Benford's Law; and 3) calculations necessary for conducting of Chi-square test and Kolmogorov-Smirnov $Z$ test. To achieve the aim of the paper it will be analysed 48 companies listed on the Zagreb Stock Exchange. Altogether 24 of analysed companies are in the process of pre-bankruptcy settlement (further in the text: "companies that are in the process"). The control group contains also 24 randomly selected companies that are not in the process of pre-bankruptcy settlement (further in the text: "companies that are not in the process"). The legal status of all companies included in this analysis was checked in the Court Register. The observed period starts in 2015 to 2018.

Table 2 Research matrix

\begin{tabular}{|l|c|c|c|}
\hline \multirow{2}{*}{ Companies' status } & \multicolumn{3}{|c|}{ Data features } \\
\cline { 2 - 4 } & $\begin{array}{c}\text { No. of observed } \\
\text { companies }\end{array}$ & $\begin{array}{c}\text { Observed } \\
\text { period }\end{array}$ & $\begin{array}{c}\text { No. of } \\
\text { data }\end{array}$ \\
\hline The companies that are not in the process & 24 & $2015-2018$ & 5,325 \\
\hline The companies that are in the process & 24 & $2015-2018$ & 4,916 \\
\hline
\end{tabular}

Source: Authors' illustration. 
The unconsolidated financial statements, balance sheet and income statements were obtained from the Zagreb Stock Exchange website and imported in Excel. For the observed period, the financial statements of 48 companies or 10,241 records were analysed (Table 2). All financial statements have auditor's opinions.

\section{Results and discussion}

Before representing the results of applying Benford's Law to financial data of the observed companies, descriptive statistics results of the first digits are shown in Table 3.

Table 3 Descriptive statistics results of first digits

\begin{tabular}{|c|c|c|c|c|}
\hline \multirow[t]{2}{*}{ Statistics } & \multicolumn{2}{|c|}{$\begin{array}{c}\text { The companies that are not in the } \\
\text { process of pre-bankruptcy } \\
\text { settlement }\end{array}$} & \multicolumn{2}{|c|}{$\begin{array}{c}\text { The companies that are in the } \\
\text { process of pre-bankruptcy } \\
\text { settlement }\end{array}$} \\
\hline & Balance sheet & Income statement & Balance sheet & Income statement \\
\hline Sample size & 3,574 & 1,751 & 3,353 & 1,563 \\
\hline Mean & 3.40 & 3.52 & 3.46 & 3.41 \\
\hline Standard deviation & 2.49 & 2.49 & 2.45 & 2.48 \\
\hline Coefficient of variation & $73.39 \%$ & $70.64 \%$ & $70.62 \%$ & $72.83 \%$ \\
\hline Skewness & 0.82 & 0.76 & 0,74 & 0.83 \\
\hline Kurtosis & -0.56 & -0.60 & -0.65 & -0.50 \\
\hline Mode & 1 & 1 & 1 & 1 \\
\hline Median & 3 & 3 & 3 & 3 \\
\hline
\end{tabular}

Source: Authors' calculation.

Table 3 shows descriptive statistics results of the first digits for the observed financial statements. The results are shown separately for the companies that are not in the process and for the companies that are in the process of pre-bankruptcy settlement by balance sheet and income statement. The observed financial data have quite similar mean values, standard deviation and are moderately positively skewed. The analysis will use a graphical approach to determine if the distribution of the first digit of observed financial statements follows Benford's Law distributions. The measure of discrepancy between empirical frequencies of observed financial companies and theoretical frequencies will be found by conduction of the chi-square test and Kolmogorov-Smirnov $\mathrm{Z}$ test.

Figure 1 shows the distribution of the first digits from the financial statements of observed companies for the period from 2015 to 2018. According to Benford's Law distribution of digit 1 should have the highest probability of occurrence, whereas the distribution of digit 9 should have the lowest. The analysis of first digit distribution from financial statements of observed companies will be made by comparing observed frequencies and Benford's Law frequency. The selected statistical tests will be used to confirm compliance to Benford's Law distribution.

Table 4 shows the actual proportion of the first digit distribution for the observed companies and expected Benford's Law distribution. The obtained results of the analysis show a similar distribution of the first digits for observed as well as for Benford's Law distribution. 


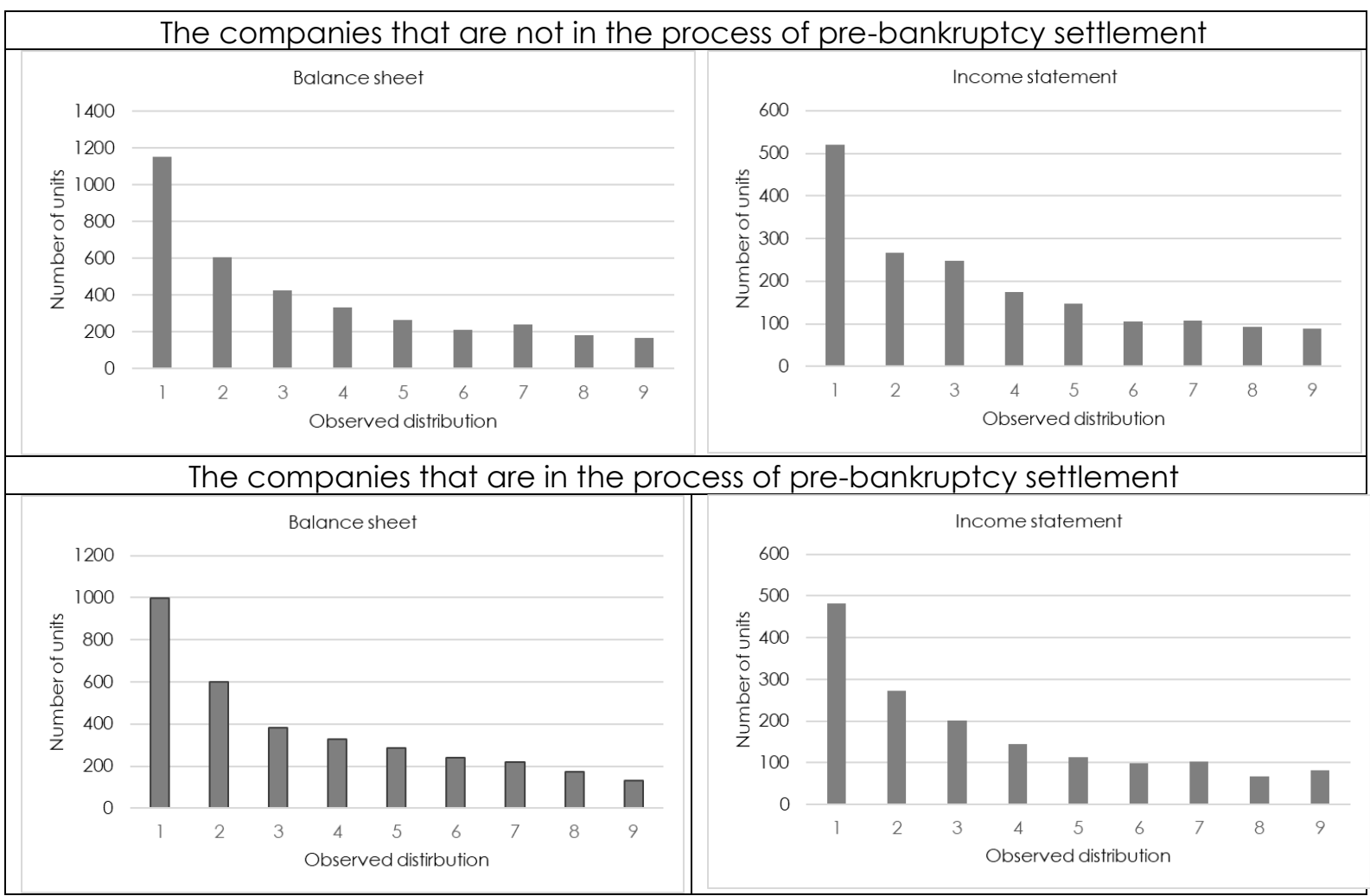

Figure 1 Distribution of the first digits - financial statements Source: Authors' calculation.

Table 4 First digit distribution from financial statements vs Benford's Law distribution

\begin{tabular}{|c|c|c|c|c|}
\hline \multirow{3}{*}{ Digit } & \multicolumn{2}{|c|}{$\begin{array}{c}\text { The companies that are not in the } \\
\text { process of pre-bankruptcy settlement }\end{array}$} & $\begin{array}{c}\text { The companies that are in the process } \\
\text { of pre-bankruptcy settlement }\end{array}$ \\
\cline { 2 - 5 } & $\begin{array}{c}\text { Observed } \\
\text { distribution } \\
\text { percent }\end{array}$ & $\begin{array}{c}\text { Benford's Law } \\
\text { distribution } \\
\text { percent }\end{array}$ & $\begin{array}{c}\text { Observed } \\
\text { distribution } \\
\text { percent }\end{array}$ & $\begin{array}{c}\text { Benford's Law } \\
\text { distribution percent }\end{array}$ \\
\hline 1 & 31.418 & 30.103 & 30.045 & 30.103 \\
2 & 16.394 & 17.609 & 17.758 & 17.609 \\
3 & 12.657 & 12.494 & 11.839 & 12.494 \\
4 & 9.484 & 9.691 & 9.581 & 9.691 \\
5 & 7.775 & 7.918 & 8.137 & 7.918 \\
6 & 5.897 & 6.695 & 6.855 & 6.695 \\
7 & 6.498 & 5.799 & 6.550 & 5.799 \\
8 & 5.089 & 5.115 & 4.862 & 5.115 \\
9 & 4.789 & 4.576 & 4.373 & 4.576 \\
\hline Total & 100.000 & 100.000 & 100.000 & 100.00 \\
\hline
\end{tabular}

Source: Authors' calculation.

Figure 2 shows that the distribution of the first digit in the observed financial data is closest to Benford's Law distribution. The graphical analyses of the cumulative density distribution of Benford's Law and cumulative density of observed data are shown in Figure 3. 


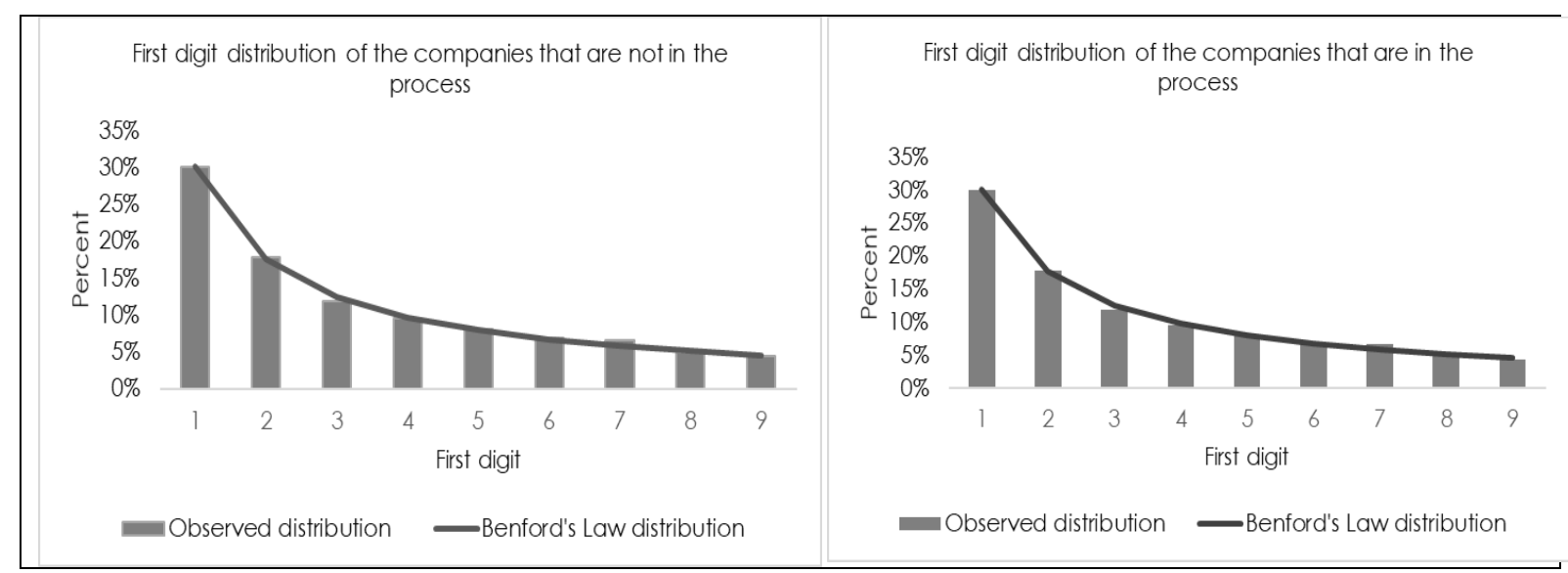

Figure 2 First digit distribution of observed financial data and Benford's Law distribution

Source: Authors' calculation.

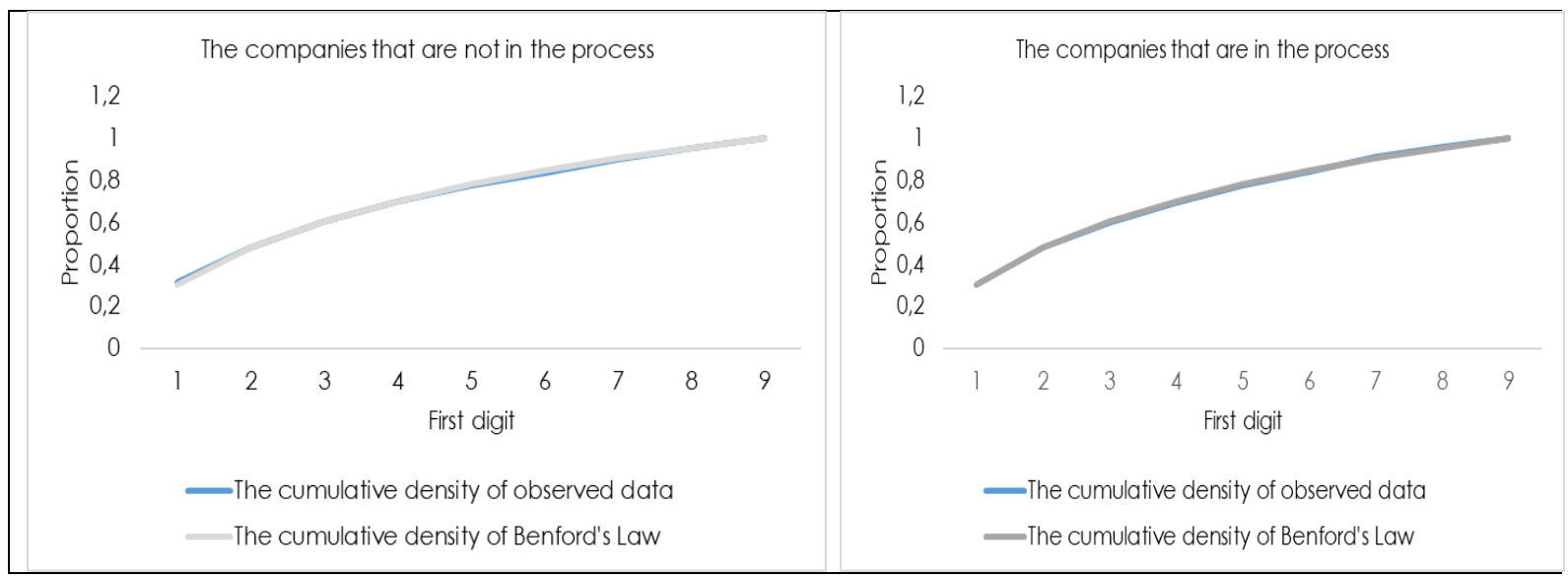

Source: Authors' calculation.

Figure 3 First digit cumulative density distribution

Table 5 Results of the chi-square test and Kolmogorov-Smirnov Z test

\begin{tabular}{|c|c|c|c|}
\hline $\begin{array}{l}\text { Statistical } \\
\text { test }\end{array}$ & Statistics & $\begin{array}{l}\text { The companies that } \\
\text { are not in the } \\
\text { process of pre- } \\
\text { bankruptcy } \\
\text { settlement }\end{array}$ & $\begin{array}{l}\text { The companies } \\
\text { that are in the } \\
\text { process of pre- } \\
\text { bankruptcy } \\
\text { settlement }\end{array}$ \\
\hline \multirow{4}{*}{$\begin{array}{l}\text { Chi-square } \\
\text { test }\end{array}$} & Test Chi-square value & 18.09 & 8.14 \\
\hline & Degrees of freedom & 8 & 8 \\
\hline & $\begin{array}{l}\text { Theoretical Chi-square } \\
\text { value at } a=0.05\end{array}$ & 15.51 & 15.51 \\
\hline & $\begin{array}{l}\text { The decision in hypothesis } \\
\text { testing }\end{array}$ & $\begin{array}{c}H_{1} \text { Hypothesis is } \\
\text { accepted at } a=0.05\end{array}$ & $\begin{array}{l}\text { Ho Hypothesis is not } \\
\text { rejected at } a=0.05\end{array}$ \\
\hline \multirow{3}{*}{$\begin{array}{l}\text { Kolmogoro } \\
\text { v-Smirnov Z } \\
\text { test }\end{array}$} & Test $Z$ value & 0.013 & 0.007 \\
\hline & $\begin{array}{l}\text { Theoretical Z value at } \\
a=0.05\end{array}$ & 0.018 & 0.019 \\
\hline & $\begin{array}{l}\text { Decision in hypothesis } \\
\text { testing }\end{array}$ & $\begin{array}{l}\text { Ho Hypothesis is not } \\
\text { rejected at } a=0.05\end{array}$ & $\begin{array}{l}\mathrm{H}_{0} \text { Hypothesis is not } \\
\text { rejected at } \mathrm{a}=0.05\end{array}$ \\
\hline
\end{tabular}

Source: Authors' calculation.

The cumulative density distribution of observed financial data confirmed that it is similar to the first digit distribution of Benford's Law. The chi-square test with 8 degrees 
of freedom and the Kolmogorov-Smirnov Z test was used to test the deviation from Benford's Law (Table 5).

Despite the Figure 2, the conducted chi-square test has shown that at the significance level of $5 \%$, the observed companies that are not in the process of prebankruptcy settlement do not have first digit distribution, which follows Benford's Law distribution. Kolmogorov-Smirnov $Z$ test has shown that, at a significance level of $5 \%$, the distribution of the first digits from the financial statements of all observed companies, fits to Benford's Law distribution.

\section{Conclusion}

Benford's Law test represents a diagnostic method for the detection of cosmetic earnings management. The aim of this paper was to analyse financial statements of companies from the Zagreb Stock Exchange and to determine whether they follow Benford's law distribution. Chi-square test and Kolmogorov-Smirnov Z test were used to check the actual proportion of the first digits in observed financial statements and to determine do they differ from Benford's Law distribution. The calculated values of the chi-square test have shown, at a significant level of $5 \%$, that the distribution of the first digits from the financial statements of companies that are not in the process of pre-bankruptcy settlement does not follow Benford's Law distribution. KolmogorovSmirnov $Z$ test has shown that, at a significance level of $5 \%$, the discrepancy from Benford's Law distributions does not exist for the financial statements of all observed companies.

The results of the selected statistical tests should be interpreted carefully since deviations from Benford's Law distribution do not always indicate fraud or manipulation in financial statements. Benford's Law test of the first digit distribution is very useful, but some forms of fraud like corruption, boosting income or kickbacks cannot be detected with Benford's Law.

This study has certain limitation. In the conduction of this study was used only the publicly available financial statements of companies listed on the Zagreb Stock Exchange. The study contains an equal number of observing companies in the sample and control group which does not correspond with the actual proportion between the companies that are not in the process and the companies that are in the process of pre-bankruptcy settlement. In future research, this limitation could be overcome by modelling the sample which is closer to the actual ratio between the companies that are not in the process and the companies that are in the process of the prebankruptcy settlement. Efforts should be included also the financial statements of companies that are not listed on the Zagreb Stock Exchange. Likewise, in the future research first digit distribution from financial statements fitness according to a law whose probability distribution is determined by specific upper bound should be analysed, as proposed by Blondeau Da Silva (2019).

\section{References}

1. Official Gazette (2012). Official Gazette 108/2012. Zakon o financijskom poslovanju i predstečajnoj nagodbi (Act on Financial Operations and Pre-Bankruptcy Settlement). NN 108/2012 (2361). Available at: novine.nn.hr/clanci/sluzbeni/2012_10_108_2361.html [01 June 2019].

2. Albrecht, W. S. (2009). Fraud Examination. South-Western Cengage Learning, Mason.

3. Amiram, D., Bozanic, Z., Roun, E. (2015). Financial statement errors: evidence from the distributional properties of financial statement numbers. Review of Accounting Studies, Vol. 20, No. 4, pp. 1540-1593. 
4. Asslani, A., Naco, M. (2014). Using Benford's Law for Fraud Detection in Accounting Practices. Journal of Social Science Studies, Vol. 1, No. 2, pp. 129-143.

5. Association of Certified Fraud Examiners (2018). 2018 Report to the Nation on Occupational Fraud \& Abuse. Available at https://www.acfe.com/report-to-the-nations/2018/ [05 October 2019].

6. Association of Certified Fraud Examiners (2008). 2008 Report to the Nation on Occupational Fraud \& Abuse. Available at https://www.acfe.com/uploadedFiles/ACFE_Website/Content/documents/2008-rttn.pdf [05 October 2019].

7. Blondeau Da Silva, S. (2019). Benford or not Benford: a systematic but not always wellfounded use of an elegant law in experimental fields. Communications in Mathematics and Statistics. arXiv:1804.06186v2 [math.PR] 12 Jun 2018. Available at: https://arxiv.org/pdf/1804.06186.pdf [15 July 2019].

8. Corazza, M., Ellero, A., Zorzi, A. (2010). Checking financial markets via Benford's law: The S\&P 500 case. In Mathematical and Statistical Methods for Actuarial Sciences and Finance, Corazza, M., Pizzi C. (Eds.), Springer, Milano, pp. 93-102.

9. Diekmann A., Jann, B. (2010). Benford's Law and Fraud Detection: Facts and Legends. German Economic Review, Vol. 11, No. 3, pp. 397-401.

10.Dumičić, K., Cunjak Mataković, I. (2019). Challenges of Benford's Law goodness-of-fit testing in discovering the distribution of first digits: comparison of two industries. In Proceedings of the 15th International Symposium on Operational Research SOR'19, Zadnik Stirn, L., Kljajić Borštnar, M., Žerovnik, J., Drobne, S., Povh, J. (Eds.), Slovenian Society Informatika, Section for Operational Research, Ljubljana, pp. 290-295.

11.Durtschi, C., Hillison, W., Pacini, C. (2004). The Effective Use of Benford's Law to Assist in Detecting Fraud in Accounting Data. Journal of Forensic Accounting, Vol. 5, No. 1, pp. 1734.

12.Hasić, T. (2014). Rokovi ispunjenja novčanih obaveza prema Zakonu o financijskom poslovanju i predstečajnoj nagodbi. Zagrebačka pravna revija - elektronički časopis poslijediplomskih studija Pravnog fakulteta Sveučilišta u Zagrebu, Vol. 3, No. 2, pp. 195-212.

13. Hill, P. T. (1995). A Statistical Derivation of the Significant-Digit Law. Statistical Science, Vol. 10, No. 4, pp. 354-363. Available at: http://digitalcommons.calpoly.edu/cgi/viewcontent.cgi?article=1042\&context=rgp_rsr [01 October 2019].

14.Hogan, C. E., Rezaee, Z., Riley, R. A., Velury, U. K. (2008). Financial Statement Fraud: Insight from the Academic Literature. Auditing: A Journal of Practice \& Theory, Vol. 27, No. 2, pp. 231-252.

15.Jošić, H., Žmuk, B. (2018). The Application of Benford's Law in psychological pricing detection. Zbornik radova Ekonomskog fakulteta Sveučilišta u Mostaru, No. 24, pp. 37-57.

16.Krakar, Z., Žgela, M. (2009). Evaluation of Benford's Low Application in Stock Prices and Stock Turnover. Informatologia, Vol. 42, No. 3, pp. 158-165.

17.Krishnan, G. V., Visvanathan, G. (2007). Reporting Internal Control Deficiencies in the PostSarbanes-Oxley Era: The Role of Auditors and Corporate Governance. International Journal of Auditing, Vol. 11, No. 2, pp. 73-90.

18. Nigrini, M. J., Miller, S. J. (2009). Data Diagnostics Using Second-Order Test of Benford's Law. Auditing, A Journal of Practice \& Theory, Vol. 28, No. 2, pp. 305-324.

19.Nigrini, M. J. (2011). Forensic Analytics: Methods and Techniques for Forensic Accounting Investigations. John Wiley \& Sons, New Jersey.

20.Omerzu, N., Kolar, I. (2019). Do the Financial Statements of Listed Companies on the Ljubljana Stock Exchange Pass the Benford's Law Test? International Business Research, Vol. 12, No. 1, pp. 54-64.

21.Papić, M., Vudrić, N., Jerin, K. (2017). Benfordov zakon i njegova primjena u forenzičkom računovodstvu. Zbornik sveučilišta Libertas, Vol. 1-2, No. 1-2, pp. 153-172.

22.Phillips, T. (2009). Simon Newcomb and "Natural Numbers" (Benford's Law). American mathematical society. Available from http://www.ams.org/publicoutreach/featurecolumn/fcarc-newcomb [02 October 2019]. 
23.Rauch, B., Göttsche, M., Brähler, G., Engel, S. (2011). Fact and Fiction in EU-Governmental Economic Data. German Economic Review, Vol. 12, No. 3, pp. 243-255.

24.Shi, J., Ausloss, M., Zhu, T. (2018). Benford's law first significant digit and distribution distances for testing the reliability of financial reports in developing countries. Physica A: Statistical Mechanics and its Applications, Vol. 492, pp. 878-888.

25.Shrestha, I. (2016). Validity of Financial Statements: Benford's Law. Available at https://www.overleaf.com/articles/validity-of-financial-statements-benfordslaw/mrmypktcsbsy [01 October 2019].

26.Singleton, T. W., Singleton, A. J. (2010). Fraud Auditing and Forensic Accounting. John Wiley \& Sons, New Jersey.

27.Slijepčević, S., Blašković, B. (2014). Statistical detection of fraud in the reporting of Croatian public companies. Financial Theory and Practice, Vol. 38, No. 1, pp. 81-96.

28.Zagreb Stock Exchange. 2013-2018. List of securities. Available at http://www.zse.hr/default.aspx?id=26474 [03 August 2019].

\section{About the authors}

Ivana Cunjak Mataković is a PhD student at University of Zagreb Faculty of Economics and Business. She graduated from the Faculty of Economics and Business, University of Zagreb, majoring in accounting, and she also gained a postgraduate master degree in auditing. She is currently employed as a certificated auditor. The author can be contacted at ivana.cunjak@gmail.com. 